\title{
Evaluation of mutagenic effects of pure hydroxyapatite doped with chromium (III) through the SMART Test in Drosophila melanogaster Meigen, 1830 (Diptera: Drosophilidae)
}

\section{Silmara de Moraes Pantaleão*, Marcio dos Santos, Heriberto A. Anjos, Alyne D. Lima, Bruno Lassmar B. Valadares, Rogeria Nunes and Maraisa B. de J. Feitosa}

Universidade Federal de Sergipe. Departamento de Biologia. Av. Mal. Rondon, S/Nº São Cristóvão. Sergipe-SE. Brasil. (CEP 49100-000). *Email: spleao51@gmail.com.

\begin{abstract}
Hydroxyapatite (HAP) is a bioceramic used in the medical and dental areas as a bone replacement factor due to its chemical similarity to the mineral phase of bones and teeth. Its use in implants stimulate the growth of bone tissue, showing no toxicity or rejection of the host tissue. Its nanostructured form has been shown to be a viable alternative for photoprotection when doped with metal ions, such as trivalent chromium $\left(\mathrm{Cr}^{+}\right)$. Due to the reach of this form among the population, this work evaluated the mutagenic potential of pure nanostructured hydroxyapatite (HAP) and doped with trivalent chromium $\left(\mathrm{Cr}^{+}\right)$(HCrIII) by means of the Somatic Mutation and Recombination Test (SMART Test) on Drosophila melanogaster Meigen, 1830 (Diptera: Drosophilidae) wings. Larvae resulting from standard crosses (ST) and high metabolic bioactivation (HB), treated with PAH and with HCrIII at concentrations $16.66 \mathrm{mg} / \mathrm{mL}, 8.33 \mathrm{mg} / \mathrm{mL}$, and $4.16 \mathrm{mg} / \mathrm{mL}$. As positive and negative controls, urethane and dodecyl sulfate sodium (SDS) were used, respectively. The frequencies of the different categories of mutant spots observed in offspring of HAP (HAP) and HCrIII treated crosses were not significantly different from those observed in the negative control. These data show that pure and chromium-doped $\left(\mathrm{Cr}^{+}{ }^{3}\right)$ nanoestructured hydroxyapatite do not exhibit mutagenicity.
\end{abstract}

Keywords: Hydroxyapatite; Chromium; Somatic Mutation and Recombination Test; SMART Test; Mutagenicity.
Received

November 18, 2017

Accepted

December 21, 2017

Released

December 31, 2017

Open Access Full Text Article

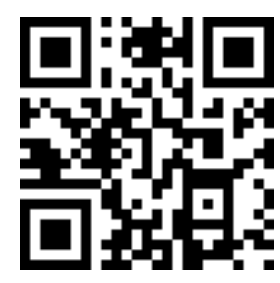

ORCID

() 0000-0001-6870-4360

Silmara de Moraes Pantaleão

(1) 0000-0002-4655-1129

Marcio dos Santos

(ㄱ) 0000-0002-9234-1085 Heriberto A. Anjos

(1) 0000-0003-1825-8934 Alyne D. Lima

(1) 0000-0002-1409-4744

Bruno Lassmar B. Valadares

(1) 0000-0001-6681-2042

Rogeria Nunes

(1) 0000-0002-2290-1585

Maraisa B. de J. Feitosa 


\section{Introduction}

Ceramics materials mainly based on calcium phosphate salts have been used in various applications in healthcare as implant materials, tissue repair and regeneration. Its wide acceptance is due mainly to its high degree of biocompatibility, since they have no local or systemic toxicity, absence of inflammation or foreign body responses and apparent ability to bind to the host tissue, as well as having great chemical similarity with the materials normally found in the bone tissue (Dourado, 2006; Lacerda et al., 2009; Trommer et al., 2006; Hench, 2013). Among bioceramics with improved performance are bioglasses, alumina, betatricalcium phosphate and hydroxyapatite (HAP). This one attracts considerable interest for being the principal mineral phase found in bone tissues and it has high biocompatibility and bioactivity, in addition to have excellent adhesion not only to the cells, but also to soft and hard tissues (Chai and Ben-Nissan, 1999; Okada and Furuzono, 2010, Wang et al., 2010). Furthermore, hydroxyapatite has great importance in many industrial applications such as catalyst support, liquid chromatography, illumination of materials, transport of substances, chemical sensors, ion conductors and drug carriers (Wang et al., 2010).

The particle size of hydroxyapatite may be decisive for its use, and the crystals obtained from preparations can vary at the scale from millimeters to nanometers (Elliott, 1994). The nanostructured hydroxyapatite has optical properties which are maximized when it acts connected with a metal ion dopant, such as trivalent chromium $\left(\mathrm{Cr}^{+} 3\right)$, so it shows great potential for application as sunscreen (Araújo et al., 2008).

The use of hydroxyapatite doped with chromium to formulate sunscreens is an important and innovative output to the cosmetics market. However, because it is a product that will interact directly with the human body, and also for being an innovative product, it is essential the conduction of several tests before the release of such material for commercialization, to prove that it does not harm the user's health especially taking into consideration that nanostructured materials have larger contact area with the skin (Araújo, 2006).

This fact may be beneficial, but can also bring risks given that when on nanoscale the materials have specific and distinct physicochemical properties, which are different from the properties of the same material at larger scales. Therefore, a product that does not bring health risks when it is at a macroscopic scale can become harmful when nanostructured (Emerich and Thanos, 2003; Sahoo and Labhasetwar, 2003; Nogueira, 2005).

Voluntarily or not, during its existence, living organisms are exposed to mutagens agents that can cause changes in the DNA sequence. Many of these changes become harmful, because they interfere in vital processes to the cells, such as DNA replication and gene transcription. These changes can result in mutations that trigger cancerous processes, which can lead eventually to cell death. So, it is important to evaluate the genotoxic and mutagenic potential of several substances, especially the new products to minimize undesirable effects on living organisms (Costa and Menck, 2000).

For this aim, the Somatic Mutation and Recombination Test (SMART Test) in Drosophila melanogaster Meigen, 1830 (Diptera: Drosophilidae) can be used as a fast, safe and reliable alternative. Through the SMART it is possible to detect point mutations, chromosomal breaks and losses and also the presence of somatic mutations when analyzed their markers, namely, through analysis of the mutant hair (Graf et al., 1984; Frei and Würgler, 1995).

Considering these facts, the present study aimed to evaluate, by means of the SMART Test in Drosophila melanogaster (fast, safe and reliable test), the possible mutagenic effects of hydroxyapatite pure and doped with $\mathrm{Cr}^{+}$. 


\section{Material and methods}

Three different lineages of D. melanogaster were used for the experiment, multiple wing hair (mwh), flare-3(flr ${ }^{3}$ ) and Oregon R, flare ${ }^{3}$ (ORR; $\left.\mathrm{flr}^{3}\right)$. These lineages were kept in an oven at controlled temperature of $25^{\circ} \mathrm{C} \pm 1{ }^{\circ} \mathrm{C}$ in glass bottles of $250 \mathrm{~mL}$ standard culture medium the basis of distilled water (820 $\mathrm{mL}$ ), biologic yeast (25 g), agar (11 g), banana (156 g) and Nipagin (1 g).

For treatment effect two types of crossings were used, the pattern - Standard Cross (ST), which characterizes the direct action of the compound investigated, and the high metabolic bioactivation - High Bioactivation Cross (HB), characterized by indirect action (Graf et al, 1984). At the Standard Cross (ST), virgin females $\mathrm{flr}^{3}$ (flr $3 / \operatorname{In}(3 L R) T M 3$, ri $p^{p}$ sep l(3)89Aa bx ${ }^{34 e}$ and $B d^{S}$ ) were crossed with males of mwh lineage with genetic constitution $\mathrm{mwh} / \mathrm{mwh}$ (Graf et al, 1984).

At the crossing $\mathrm{HB}$, virgin females of the lineage ORR/flr ${ }^{3} \quad(O R R / O R R$ : $f l r^{3} / \operatorname{In}(3 L R) T M 3$, ri $p^{p}$ sep l(3)89Aa bx ${ }^{34 e}$ and $B d^{S}$ were used with $m w h / m w h$ male. The ORR/flr $r^{3}$ females carry chromosomes 1 and 2 from the lineage Oregon R (R), DDTresistant (Dapkus and Merrell, 1977). These genes are responsible for high levels of metabolic enzymes of the Cytochrome P450 (CYP6A2) type (Graf and Schaik, 1992). From both crosses two kinds of larvae were originated: the trans-marked heterozygous (MH) which have regular/smooth edges of wings and the balanced larvae heterozygous $(\mathrm{BH})$ for chromosome TM3, which have irregular/serrated edge of wings, which were exposed to the tested substances.

Samples of nanostructured hydroxyapatite pure and doped with $\mathrm{Cr}^{+3}$ at the concentration of $1 \% \mathrm{~mol}$ were used for treatment. Sodium dodecyl sulphate (SDS) at $3 \%$, which in this experiment was used as a solvent because it proved to be more efficient than distilled water at the dispersion of hydroxyapatite's molecules, was used as the negative control and urethane (URE) $0.891 \mathrm{mg} / \mathrm{mL}$ as the positive control. For each treatment three concentrations were determined and for each concentration three repetitions were determined. The concentrations that were determined for both treatment are 16.66 $\mathrm{mg} / \mathrm{mL}, 8.33 \mathrm{mg} / \mathrm{mL}$, and $4.16 \mathrm{mg} / \mathrm{mL}$.

For each treatment $80 \mathrm{flr}^{3}$ virgin females were used (standard cross - ST) and 80 ORR, flr ${ }^{3}$ virgin females (crossing with high bioactivation - HB) with $40 \mathrm{mwh}$ males in separated bottles per crossing, containing standard culture medium for two days. After this period the parental flies were transferred to other containers of about $400 \mathrm{~mL}$, which contained oviposition medium-based agar, biological yeast and sugar, all cooked in a water bath at a temperature of $38^{\circ} \mathrm{C} \pm 2{ }^{\circ} \mathrm{C}$, where they remained for $8 \mathrm{~h}$. Afterwards the adults were discarded. $72 \mathrm{~h} \pm 4 \mathrm{~h}$ after the beginning of oviposition, the larvae of the third stage were collected by flotation in flowing water at $25{ }^{\circ} \mathrm{C}$ through a metal strainer with fine mesh (Graf et al, 1984).

These collected larvae were placed in smaller containers (approximately 100 per container) containing $1.5 \mathrm{~g}$ of synthetic medium (yoki ${ }^{\circledR}$ mashed potatoes) and $5 \mathrm{~mL}$ of the solution to be tested treatment. This procedure was the same for both controls as negative to positive. The larvae remained under these conditions for about $48 \mathrm{~h}$ (chronic treatment), until reaching the emergence of the larvae. All adults derived from the treatments were maintained in $70 \%$ ethanol until the assembly of blades. For this step, the wings were extracted in stereomicroscope and mounted between blade and coverslip with Faure solution (30 g of arabic gum, $20 \mathrm{~mL}$ of glycerol, $50 \mathrm{~g}$ of chloral hydrate and $50 \mathrm{~mL}$ of water) and analyzed for the occurrence of different types of mutant spots in a light optical microscope, at increased 400x. Statistical analysis was performed according to the chi-square (X2) proposed by Frei and Würgler (1988), for two-tailed proportions significance level: $\alpha=\beta=0.05$, in order to compare the frequencies obtained from the groups which were treated with the negative control frequency. 


\section{Results and discussion}

Hydroxyapatite (HAP) has been used successfully for a long time in the medical implant and bone tissue repair, as a biocompatible and bioactive material cytologically. But in recent years, it has attracted attention as an excellent alternative for environmental control, as biosensor and intelligent drugs vehicle (Araújo et al, 2008). In its most recent use, nanostructured hydroxyapatite doped with chromium $\left(\mathrm{Cr}^{+}{ }^{3}\right)$ has been studied as a viable alternative for the production of sunscreen. In this study samples of pure nanostructured hydroxyapatite and nanostructured hydroxyapatite doped with $\mathrm{Cr}^{3}+1 \%$ mol at different concentrations $(16.66 \mathrm{mg} / \mathrm{mL}, \quad 8.33 \mathrm{mg} / \mathrm{mL}$, and 4.16 $\mathrm{mg} / \mathrm{mL}$ ) were tested through the SMART Test, and the respective controls: positive (urethane $0.891 \mathrm{mg} / \mathrm{mL}$ ) and negative (sodium dodecyl sulphate - 3\% SDS). The controls, positive and negative, were simultaneously tested in each experiment and the results obtained in the isolated treatments were compared to negative control.

\section{Mutagenic analysis of pure hydroxyapatite (HAP)}

Table 1 shows the results of the frequencies of mutant spots observed in the $\mathrm{MH}$ descendants for both crossings (ST and HB), treated with different concentrations of pure Hydroxyapatite (HA) and their respective controls. For this treatment, the frequency of mutant spots - the small simple ones, the large simple ones and the twins, as well as the total number of spots observed were not statistically significant ( $\alpha$ $\leq 0.05$ ) when compared to their respective negative controls for the two crossings, both ST as HB.

Table 1. Frequency of mutant spots observed in the MH descendants wings of $D$. melanogaster from ST and $\mathrm{HB}$, after chronic treatment $(\sim 48 \mathrm{~h})$ with different concentrations $(16.66 \mathrm{mg} / \mathrm{mL}, 8.33 \mathrm{mg} / \mathrm{mL}, 4.16$ $\mathrm{mg} / \mathrm{mL}$ ) of pure nanostructured hydroxyapatite and its respective controls: negative (3\% SDS) and positive (URE $0.891 \mathrm{mg} / \mathrm{mL}$ ).

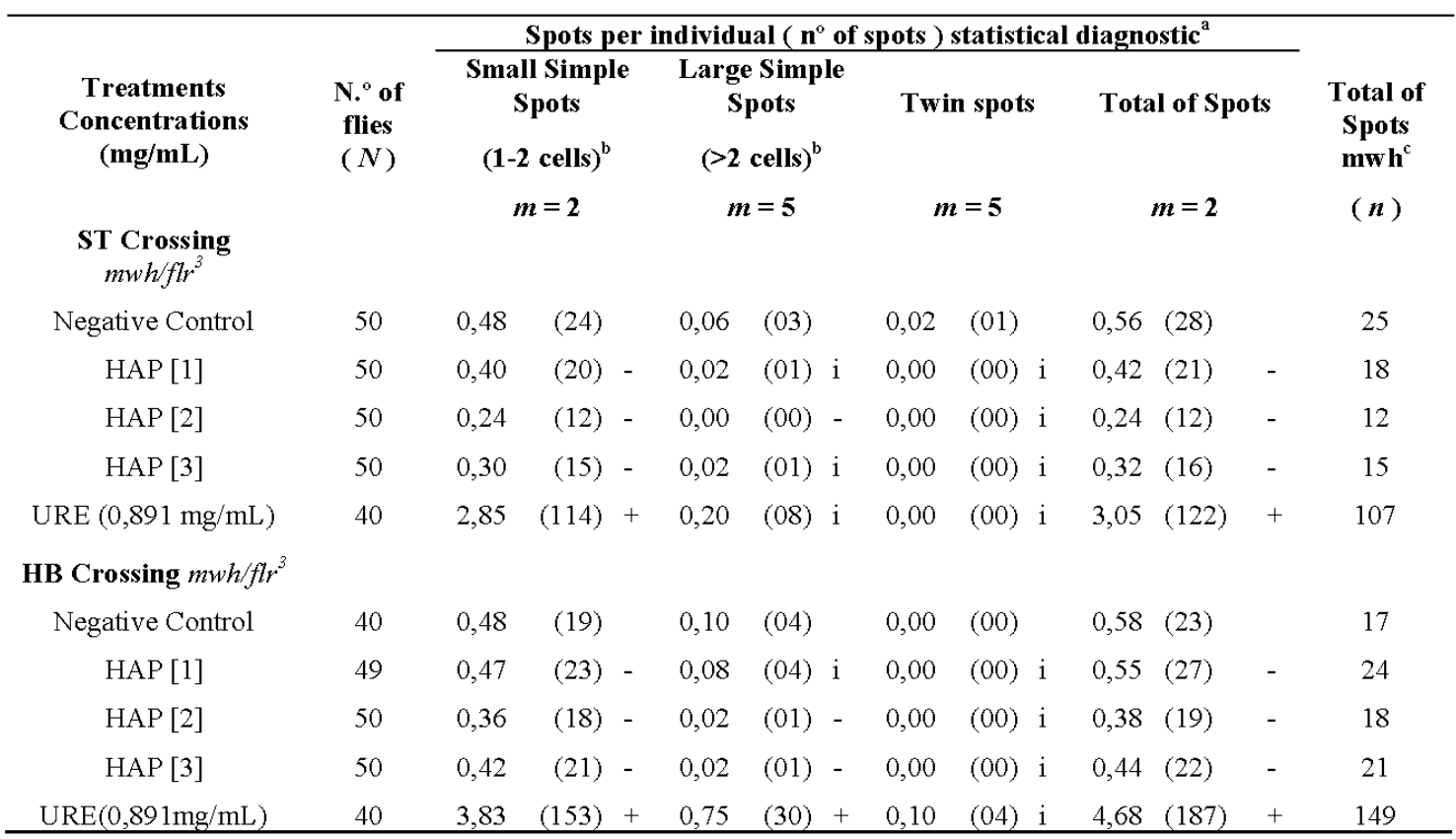

HAP = Pure Hydroxyapatite $;$ URE = Urethane; HAP [1] = 16.66 mg/mL, HAP [2] = 8.33 mg/mL, HAP [3] = $4.16 \mathrm{mg} / \mathrm{mL}$. ${ }^{a}$ Statistical diagnoses according to Frei and Würgler (1988): +, positive; -, negative; i, inconclusive. $m$, multiplication factor for the evaluation of the significantly negative results. Significance levels $\alpha=\beta=0,05$. ${ }^{\mathrm{b}}$ Including rare simple spots $\mathrm{flr}^{3}$. Considering mwh clones for mwh simple spots and for twin spots. 
Chronic treatment of $\mathrm{MH}$ individuals with HA dissolved in 3\% SDS resulted in a predominant distribution of simple and small spots for both crossings (ST and HB), indicating that the mutations observed in the cells of the wings' imaginal discs occurred at a late larval stage of the development of $D$. melanogaster, passing through one or two cycles of cell division in maximum once the larvae are exposed to the substances for 5 or 6 mitotic cycles, which correspond to $95 \%$ of all cell divisions that occur from the developing embryo to the beginning of the pupal stage (Frei et al., 1992). The large spots are formed by mutations, which occurred in the initial development stages passing through several cycles of cell division and, for this reason, it shows a higher number of cells per spot. Thus, in experiments with substances that have immediate genotoxic action, it is expected to find a prevalence of large spots, differently from what happened in this study.

The negative results found in $\mathrm{MH}$ descendants from the high bioactivation crossing (HB) permit the inference that HA under the experimental conditions used is not a pro-mutagenic agent, or with indirect action, dependent on metabolization, and that cytochrome P450 enzymes do not influence the genotoxic potential of this substance. Hydroxyapatite is widely used for medical application because of its high biocompatibility and low toxicity, even when it is in nanometric structure (Okada and Furuzono, 2010; Tomoda et al., 2010; Kumar et al., 2010; Wang et al., 2010a). Gouveia (2008) demonstrated through the CellTiter96® AQueous test that nanostructured hydroxyapatite is not cytotoxic. However, Motskin et al. (2009), testing hydroxyapatite nanopowders, they concluded that when nanostructured it assumes different physicochemical characteristics, but only becomes cytotoxic at higher concentrations. But there were no reports in the literature about tests for mutagenicity of nanostructured hydroxyapatite that could be compared to the results found in this study.

\section{Mutagenic analysis of hydroxyapatite doped with trivalent chromium (HCrIII)}

Table 2 shows the results of the frequencies of mutant spots in $\mathrm{MH}$ descendants for both crossings (ST and HB), treated with different concentrations of hydroxyapatite doped with trivalent chromium (HCrIII) and their respective controls. The frequency of total mutant spots observed on treatment with different concentrations of HCrIII were not statistically significant when compared to the frequencies of mutant spots found in their respective negative controls for the two crossings (ST and HB).

For the ST crossing, the frequency of large and simple spots was not statistically significant for any of the three concentrations when compared to negative control. The total of mutant spots showed no significant difference in any of the three concentrations when compared to the negative control, which indicates lack of genotoxicity of HCrIII. For $\mathrm{MH}$ descendants treated with HCrIII from the HB crossing, the results were similar to those from the ST crossing, because the frequency of simple spots as well as the total of mutant spots was not statistically significant for any of the three concentrations when compared to its negative control. For the descendants of the two crossings (ST and HB), HCrIII, although it has not showed statistically different results from the negative control, showed a higher frequency of small and simple spots, similar to the result of HAP. This indicates that mutations in the cells occured at a late stage in embryonic development of the larvae of D. melanogaster.

Under the experimental conditions used, HCrIII did not behave as a promutagenic or with indirect action, since the $\mathrm{MH}$ descendants from HB crossing did not show statistically different results from negative control in any of the three concentrations that was analyzed, so it is not dependant on metabolization by cytochrome P450 enzymes. 
Table 2. Frequency of mutant spots observed in $\mathrm{MH}$ descendants wings of $D$. melanogaster from ST and $\mathrm{HB}$, after chronic treatment ( 48h) with different concentrations $(16.66 \mathrm{mg} / \mathrm{mL}, 8.33 \mathrm{mg} / \mathrm{mL}$, and $4.16 \mathrm{mg} / \mathrm{mL}$ ) of nanostructured hydroxyapatite doped with $\mathrm{Cr} 3+$ and its respective controls: negative (3\% SDS) and positive (URE $0.891 \mathrm{mg} / \mathrm{mL}$ ).

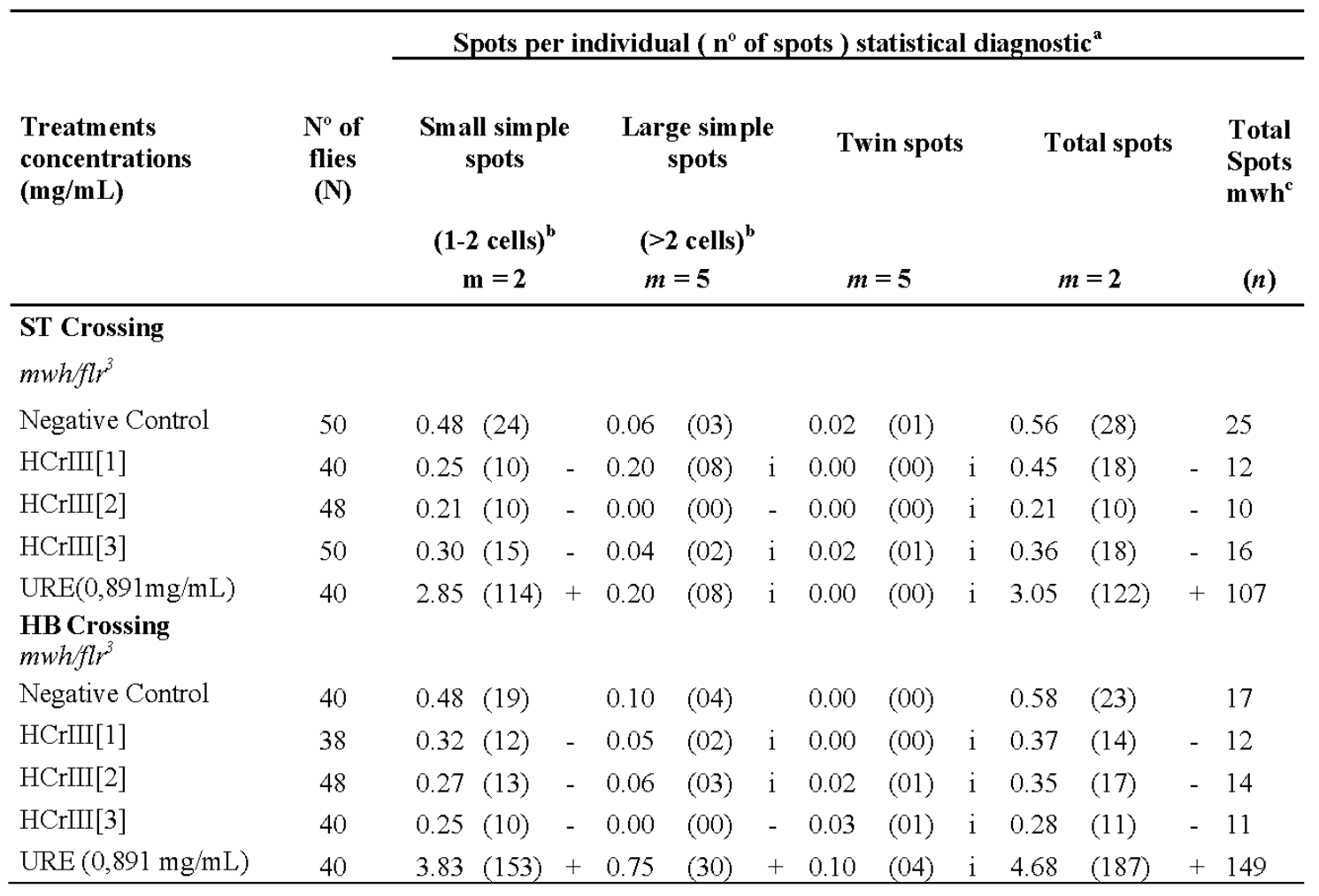

HCrIII = Hydroxyapatite doped with Trivalent Chromium $\left(\mathrm{Cr}^{3}\right)$; URE = Urethane; HCrIII[1] = $16.66 \mathrm{mg} / \mathrm{mL}$, HCrIII [2] = $8.33 \mathrm{mg} / \mathrm{mL}$, HCrIII [3] = $4.16 \mathrm{mg} / \mathrm{mL}$. ${ }^{\text {a }}$ Statistical diagnoses according to Frei and Würgler (1988): +, positive; -, negative; i, inconclusive. m, multiplication factor for the evaluation of the significantly negative results. Significance levels $\alpha=\beta=0,05$. ${ }^{\text {Including rare simple }}$ spots $\mathrm{flr}^{3}$. 'Considering mwh clones for mwh simple spots and for twin spots.

The trivalent chromium at high concentrations and long exposure is genotoxic (Çavaş and Ergene-Gözükara, 2005), although this compound has not shown genotoxicity in SMART (Graf and Singer, 1992).

The $\mathrm{Cr}^{+} 3$ is an essential component for some biological activities, such as glucose metabolism and it does not show toxicity at low concentrations. However, $\mathrm{Cr}^{+}{ }^{3}$ compounds such as chromium chloride $\left(\mathrm{CrCl}_{3}\right)$ can be genotoxic in vitro leading to induction of micronuclei (MN) in human fibroblasts, according to study by Seoane and Dulout (2001). In a similar study with tannery workers exposed to $\mathrm{Cr}^{+}{ }^{3}$, Meibian et al. (2008) demonstrated that this metal can cause DNA damage to human lymphocytes.
But, despite these studies, HCrIII showed no mutagenic activity under the experimental conditions used. Also, no work was found in the literature about HCrIII mutagenicity test.

\section{Conclusions}

In the experimental conditions used nanostructured hydroxyapatite both pure as doped with trivalent chromium $\left(\mathrm{Cr}^{+}\right)$at $1 \%$ mol, is not mutagenic nor with direct action nor with indirect action, dependent on metabolization. Moreover, hydroxyapatite doped with trivalent chromium showed similar results to those obtained from the analysis of mutagenicity of pure hydroxyapatite, so it is possible to conclude that, in this experiment, the presence of 
chromium had no effect on its mutagenic potential. Nanostructured hydroxyapatite pure and doped with $\mathrm{Cr}^{+}$, based on experimental conditions used, showed results that support the safe use as raw material base for the manufacturing of products for human use, as sunscreen, for example.

\section{Acknowledgments}

We are grateful to the Brazilian funding agency $\mathrm{CNPq}$ and CAPES for financial support.

\section{Conflicts of interest}

Authors declare that they have no conflict of interests.

\section{References}

Araújo, T. S. Produção de hidroxiapatita pura e dopada para aplicação em biosensores. São Cristóvão: Universidade Federal de Sergipe, 2006.

Araújo, T. S.; Lima, T. A. R. M.; Nunes, R. S., Lalic, S. S. Produção de filtros solares inorgânicos contendo hidroxiapatita. Anais do XXXI Encontro Nacional de Física da Matéria Condensada, Águas de Lindóia, 2008.

Çavaş, T.; Ergene-Gözükara, S. Induction of micronuclei and nuclear abnormalities in Oreochromis niloticus following exposure to petroleum refinery and chromium processing plant effluents. Aquatic Toxicology, v. 74, no. 3, p. 264-271, 2005. https://doi.org/10.1016/j.aquatox.2005.06.001

Chai, C. S.; Ben-Nissan, B. Bioactive nanocrystalline sol-gel hydroxyapatite coatings. Journal of Materials Science: Materials in Medicine, v. 10, n. 8, p. 465-469, 1999. https://doi.org/10.1023/A:1008992807888

Costa, R. M. A.; Menk, C. F. M. Biomonitoramento de mutagênese ambiental. Biotecnologia Ciência \& Desenvolvimento, v. 2, p. 24-26, 2000.

Dapkus, D.; Merrell, D. J. Chromosomal analysis of DDT-resistance in a long-term selected population of Drosophila melanogaster. Genetics, v. 87 , no. 4, p. 685697, $1977 . \quad$ Available from: <http://www.genetics.org/content/genetics/87/4/ 685.full.pdf $>$. Accessed on: Apr. 27, 2017.
Dourado, E. R. Preparação e caracterização de hidroxiapatita nanoestruturada dopada com estrôncio. Rio de Janeiro: Centro Brasileiro de Pesquisas Físicas, 2006. (Master Dissertation).

Elliott, J. C. Structure and chemistry of the apatites and other calcium orthophosphates. Studdies in Organic Chemistry, v. 18, p. 1-62, 1994. http://doi.org/10.1016/B978-0-44481582-8.50006-7

Emerich, D. F.; Thanos, C. G. Nanotechnology and medicine. Expert Opinion on Biological Therapy, v. 3, no. 4, p. 655-663, 2003. https://doi.org/10.1517/14712598.3.4.655

Frei, H.; Clements, J.; Howe, D.; Würgler, F. E. The genotoxicity of the anti-cancer drug mitoxantrone in somatic and germ cells of Drosophila melanogaster. Mutation Research/Environmental Mutagenesis and Related Subjects, v. 279, no. 1, p. 21-33, 1992. https://doi.org/10.1016/0165-1161(95)90018-7

Frei, H.; Würgler, F. E. Optimal experimental design and sample size for the statistical evaluation of data from somatic mutation and recombination tests (SMART) in Drosophila.

Mutation Research/Environmental Mutagenesis and Related Subjects, v. 334, no. 2, p. 247-258, 1995. https://doi.org/10.1016/ 0165-1161(95)90018-7

Frei, H.; Würgler, F.E. Statistical methods to decide whether mutagenicity test data from Drosophila assays indicate a positive, negative, or inconclusive result. Mutation Research/Environmental Mutagenesis and Related Subjects, v. 203, no. 4, p. 297-308, $1988 . \quad$ https://doi.org/10.1016/01651161(88)90019-2

Graf, U.; Singer, D. Genotoxicity testing of promutagens in the wing somatic mutation and recombination test in Drosophila melanogaster. Revista Internacional de Contaminación Ambiental, v. 8, p. 15-27, 1992. Available from: <http://www.revistascca.unam.mx/ rica/index.php/rica/article/viewFile/29290/2724 5>. Accessed on: Mar. 23, 2017.

Graf, U.; Van Schaik, N. Improved high bioactivation cross for the wing somatic mutation and recombination test in Drosophila melanogaster. Mutation Research/ Environmental Mutagenesis and Related Subjects, v. 271, no. 1, p. 59-67, 1992. https://doi.org/10.1016/0165-1161(92)90032-H

Graf, U.; Würgler, F. E.; Katz, A. J.; Frei, H.; Juon, H.; Hall, C. B.; Kale, P. G. Somatic mutation and recombination test in Drosophila melanogaster. Environmental Mutagenesis, 


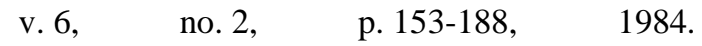
https://doi.org/10.1002/em.2860060206

Hench, L. L. An introduction to bioceramics. 2. ed. Shanghai: Imperial College Press, 2013.

Kumar, G. S.; Girija, E. K.; Thamizhavel, A.; Yokogawa, Y.; Kalkura, S. N. Synthesis and characterization of bioactive hydroxyapatitecalcite nanocomposite for biomedical applications. Journal of Colloid and Interface Science, v. 349, no. 1, p. 56-62, 2010. https://doi.org/10.1016/j.jcis.2010.05.038

Lacerda, K. A.; Lameiras, F. S.; Silva, V. V. Avaliação da biodegradação de matrizes porosas à base de hidroxiapatita para aplicação como fontes radioativas em braquiterapia. Química Nova, v. 32, no. 5, p. 1216-1221, 2009. https://doi.org/10.1590/S0100-40422009000 500025

Meibian, Z.; Zhijian, C.; Qing, C.; Hua, Z.; Jianlin, L.; Jiliang, H. Investigating DNA damage in tannery workers occupationally exposed to trivalent chromium using comet assay. Mutation Research/Genetic Toxicology and Environmental Mutagenesis, v. 654, no. 1, p. 45-51, 2008. https://doi.org/10.1016/ j.mrgentox.2008.04.011

Nogueira, N. A. S. Sinterização de nanopartículas de $\mathrm{NiAl}_{2} \mathrm{O}_{4}$ por gelatina comestível. Fortaleza: Universidade Federal do Ceará, 2005. (Master dissertation).

Okada, M.; Furuzono, T. Hydroxyapatite nanocrystal coating on biodegradable microspheres. Material Sciencie and Engineering B, v. 173 , no. $1 / 3$, p. 199-203, 2010. https://doi.org/10.1016/j.mseb.2009. 12.009
Sahoo, S. K.; Labhasetwar, V. Nanotech approaches to drug delivery and imaging. Drug Discovery Today, v. 8, no. 24, p. 1112-1120, $2003 . \quad$ https://doi.org/10.1016/S13596446(03)02903-9

Seoane, A. I.; Dulout, F. N. Genotoxic ability of cadmium, chromium and nickel salts studied by kinetochore staining in the cytokinesis-blocked micronucleus assay. Mutation Research/ Genetic Toxicology and Environmental Mutagenesis, v. 490, no. 2, p. 99-106, 2001. https://doi.org/10.1016/S1383-5718(00)00145-5

Tomoda K, Ariizumi H, Nakaji T, Makino K. Hydroxyapatite particles as drug carriers for proteins. Colloids Surfaces B Biointerfaces, $\begin{array}{llll}\text { v. } 76, & \text { n. } 1, & \text { p. 226-235, } 2010 .\end{array}$ https://doi.org/10.1016/j.colsurfb.2009.10.039

Trommer, R. M.; Santos, L. A.; Bergmann C. P. Obtenção e caracterização de revestimentos de hidroxiapatita sobre substratos de aço inoxidável 316L utilizando a técnica de deposição química de vapor. Anais do $17^{\circ}$ Congresso Brasileiro de Engenharia e Ciência dos Materiais, Foz do Iguaçu, 2006.

Wang, S.; Lei, Y.; Zhang, Y.; Tang, J.; Shen, G.; Yu, R. Hydroxyapatite nanoarray-based cyanide biosensor. Analytical Biochemistry, v. 398, no. 2, p. 191-197, 2010. https://doi.org/10.1016/j.ab.2009.11.029

Wang, P.; Li, C.; Gong, H.; Jiang, X.; Wang, $\mathrm{H}$.; Li, K. Effects of synthesis conditions on the morphology of hydroxyapatite nanoparticles produced by wet chemical process. Powder Technology, v. 203, no. 2, p. 315-321, 2010. https://doi.org/10.1016/j.powtec.2010.05.023 